\title{
Crowdfunding: New Financing Tool for Social and Solidarity Economy in Morocco
}

\author{
Reda Sahmi ${ }^{1}$, Mostafa El Hachloufi ${ }^{1}$ \& Meriem Aboulethar ${ }^{1}$ \\ ${ }^{1}$ Hassan II University, Fsjes Ain Sebaa, Morocco \\ Correspondence: Reda Sahmi, Hassan II University, Fsjes Ain Sebaa, Morocco.
}

Received: June 3, 2021

Accepted: June 24, 2021

Online Published: July 15, 2021

doi:10.5430/ijfr.v12n4p294

URL: https://doi.org/10.5430/ijfr.v12n4p294

\begin{abstract}
Alternative forms of financing have emerged recently, such as solidarity finance, crowdfunding and participatory finance. They provide innovative solutions to the financial problems faced by economic agents wishing to carry out projects with significant social and environmental impact.

In fact, these alternative forms of financing aim at proposing unprecedented alternatives and complementary financing offers that can help the actors of Social and Solidarity Economy (SSE) to concretize their projects. For this purpose, we are developing an analysis of the major assets and the distinguished opportunities that Crowdfunding will bring to SSE actors in Morocco. We will also examine how it can become one substitute of classical finance in Morocco.
\end{abstract}

Keywords: social and solidarity economy, crowdfunding, classic finance, social impact, investment

\section{Introduction}

Over the past few years, Morocco has committed itself to ambitious and proactive public policies aimed at the country's socio-economic development and which are in full harmony with the challenges of globalisation. In fact, the rationale that public authorities provide behind these policies is to ensure strong and sustainable economic development.

In the same way, the royal speeches recognise the role that the Social and Solidarity Economy (SSE) can play in the sustainable development of the country, the public authorities have focused their investment efforts on this logic of sustainability in order to promote the SSE.

Indeed, in recent years we have seen several investments that have affected many sectors of SSE. However, it should be noted that the development of this sector is conditioned by several factors, among which we find the optimal use of the financial resources that are and will be mobilised in its favour. To this end, this research, attempts to illustrate the added value that crowdfunding can bring to further develop SSE in Morocco. Two central questions may be raised in this regard:

Could crowdfunding be an effective alternative to finance and develop the solidarity and social economy in Morocco? Would the products offered by crowdfunding allow for more flexible and accessible financing for SSE actors in Morocco?

\subsection{Research Hypothesis}

H1: The crowdfunding products present an effective solution for the development of the social and solidarity economy in Morocco.

$\mathrm{H} 2$ : The types of products offered by crowdfunding in Morocco do not present any added value for the development of the social and solidarity economy.

This article is structured as follows: To begin with, the concept of "crowdfunding" is presented with the aim of explaining its different modes of operation offered to economic agents.

Equally interesting is the historical evolution of this new financing alternative, its different actors as well as its main products. The second part of this article focuses on the role that crowdfunding could play in the development of SSE in Morocco. We conducted an empirical investigation in order to study the impact of Crowdfunding on SSE in 


\section{Morocco.}

\section{Crowdfunding: A New Financing Alternative in Morocco}

\subsection{Literature Review}

Crowdfunding is a recently coined term in which "crowd" denotes 'the large public' and "funding" refers to the operations of financing. Therefore, the concept of crowdfunding is a form of crowdsourcing. The latter uses the general public to get new ideas, suggestions and solutions to develop activities in favour of entrepreneurs.

The objective of crowdfunding is simply to raise funds, generally small amounts, from a rather large, number of investors in order to finance innovative, cultural projects with strong social and economic impacts. It therefore helps to strengthen the financial inclusion of entrepreneurs, to support economic and social development and to lead collective savings into new opportunities. To perform a crowdfunding operation, it is imperative to go through Internet platforms allowing putting in contact the project holders, those who ask for financial aid, with the financial backers, those who wish to invest or subsidize the entrepreneurs' projects. The "Crowdfunding" concept was first invented in August 2006 by Michael Sullivan.

When we explore the literature on crowdfunding, we realize that there is no universal and precise definition of this concept. According to Lambert \& Shwienbacher (2010), crowdfunding is defined as "an open call, primarily through the Internet, for the provision of financial resources, in the form of a donation in exchange for some form of reward to support specific purpose initiatives". According to (Bechter \& al., 2011), crowdfunding refers to an approach to raising capital for a project or business by appealing to large numbers of people for small ( $\$ 1-\$ 100)$ contributions. For its part, Lynn, (2012) describes crowdfunding as a new extension of social media that provides funding for a variety of businesses. In the opinion of Ramsey (2012), the concept is defined as a fundraising process to help turn promising ideas into commercial realities by connecting investors with potential supporters. On the other hand, Powers (2012), crowdfunding refers to a financial mechanism that allows businesses to start up by soliciting funds from the general public through websites. For their part Byrnes, Wang \& Ranganathan (2012), argue that crowdfunding is a new, internet-based method of fundraising in which individuals solicit contributions for projects on specialised crowdfunding sites. From all these definitions, we deduce that crowdfunding can be seen as an approach, a mechanism, a method and a process, which makes it possible to raise funds from savers, through platforms, to finance and support project leaders. Moreover, according to Hemer (2011) and (Gerber \& al., 2012), crowdfunding is a financing method mainly intended for project leaders who encounter constraints in raising funds in the early stages of a project that is too risky and complex in the eyes of the banks. Crowdfunding is currently seen as a new financing alternative, which has become increasingly popular in several countries around the world. Specifically, a new model for financing projects on the Internet is being put in place. Crowdfunding, as a new method of financing, will be operational via internet platforms enabling direct and transparent contact between project leaders and donors. Crowdfunding in Morocco will take three forms: crowdlending, Crowdequity and donation crowdfunding.

\subsection{Historical Evolution of Crowdfunding}

Historically, crowdfunding is not a very recent form of financing. In fact, many projects have been funded by appealing to the general public. For instance, the pedestal of the Statue of Liberty in New York, was financed in 1888 by micro-donations from Americans. Some $\$ 400.000$ was raised to enable the construction of this famous monument. Even before that, the famous composers Beethoven and Mozart repeatedly appealed to the general public to finance and perform some of their works. In Morocco, there has also been a major fundraising campaign among the public to build the Hassan II Mosque in Casablanca. Indeed, more than 3 billion Dirhams were collected after the late Moroccan King Hassan II announced that the construction of the mosque would be financed by popular subscription.

However, the advent of the Internet has exponentially accelerated crowdfunding thanks to the exchange platforms between project leaders and funders. KIVA (Note 1) is the first site in the world that had proposed an interface, the purpose of which is to collect donations in order to support the projects of young people living in a developing country. The site was created in 2005 and the contributors are mainly microfinance financial institutions and non-profit associations. IndieGogo (Note 2) is the first platform in the world to have generalised the crowdfunding model. It has contributed to the realisation of 800.000 innovative ideas since 2008. It currently brings together more than 9 million donors from 235 territories around the world. Several other platforms have subsequently emerged.

Take Kickstarter (Note 3) as an example; the platform is based in the United States, which has rapidly built up a good reputation throughout the world because of the diversity of the projects it proposes and the size of the amounts it manages to collect. Until Juin 2021, Kickstarter was able to raise US\$5.913 billion to fully fund 203.911 projects 
with 19.851 .868 contributors with 73.297 .871 contributions. Another example is KissKissBankBank (Note 4), the French platform which, since 2009, has raised 113.315.128 Euros to finance a total of 22,825 projects. The project categories as well as the amount of funds raised are listed in the table below:

Table 1. Statistics of crowdfunded projects in 2020 (KissKissBankBank Platform)

\begin{tabular}{lllll}
\hline Category & Funds raised & Succeful projects & Number of contributions & Average Contributions \\
\hline Solidarity & $19.399 .234 €$ & 4.226 & 274.413 & $71 €$ \\
\hline Music & $16.775 .273 €$ & 3.668 & 285.523 & $59 €$ \\
\hline Écology & $15.653 .092 €$ & 2.227 & 222.319 & $70 €$ \\
\hline Health \& Education & $13.229 .577 €$ & 2.782 & 190.279 & $70 €$ \\
\hline Art \& photo & $12.681 .022 €$ & 3.147 & 203.435 & $62 €$ \\
\hline Books & $9.368 .174 €$ & 1.193 & 168.257 & $56 €$ \\
\hline Films \& video & $9.314 .299 €$ & 1.777 & 150.627 & $62 €$ \\
\hline Foods & $9.082 .804 €$ & 1.214 & 125.019 & $73 €$ \\
\hline Sport & $9.037 .035 €$ & 2.256 & 119.526 & $76 €$ \\
\hline Fashion \& design & $7.332 .932 €$ & 1.199 & 84.820 & $86 €$ \\
\hline Theatre and dance & $6.308 .416 €$ & 1.809 & 100.396 & $63 €$ \\
\hline Journalism & $6.056 .944 €$ & 525 & 108.735 & $56 €$ \\
\hline Agriculture & $4.931 .604 €$ & 684 & 66.239 & $74 €$ \\
\hline Crafts & $4.824 .525 €$ & 800 & 62.889 & $77 €$ \\
\hline Heritage & $3.350 .132 €$ & 574 & 45.758 & $73 €$ \\
\hline Technology & $2.792 .407 €$ & 324 & 34.985 & $80 €$ \\
\hline Comics & $1.861 .846 €$ & 188 & 34.491 & $54 €$ \\
\hline Games & $954.310 €$ & 132 & 14.010 & $68 €$ \\
\hline
\end{tabular}

Source: KissKissBankBank- Crowdfunding Platform in French.

\subsection{Actors and Types of Crowdfunding}

As mentioned in the definition section, crowdfunding is a very recent method of financing which makes it possible to finance any type of project with a social and economic impact on society by relying on financial contributions from the general public without using the traditional financing circuit (banks or other financial institutions). However, the financing of projects via crowdfunding requires, in addition to the internet, the intervention of certain economic actors, in particular: The project leader, The contributor, The Crowdfunding platform.

The platforms play the role of intermediaries and allow direct contact between the investor and the project leader. They accompany and explain the crowdfunding process to stakeholders so that both understand the risks and responsibilities of the operations. Indeed, control of the process, whether on the project leader's or investor's side, helps to avoid any slippage or malfunction of the operation. We also point out that there are two types of crowdfunding platforms, specifically speculative and non-speculative platforms. The speculative platforms represent a complement to traditional finance (banking circuit) and offer an alternative for the financing of very small and medium-sized enterprises. While non-speculative platforms are differentiated by the solidarity of investors. 
Table 2. Differences between speculative and non-speculative platforms

\begin{tabular}{ll}
\hline Speculative Platform & Non-Speculative Platform \\
\hline $\begin{array}{l}\text {-The loan with interest: the investor demands the } \\
\text { repayment of his loan with interest; }\end{array}$ & $\begin{array}{l}\text { - Donation without counterpart: in this case the } \\
\text { general public finances projects of a } \\
\text { philanthropic nature; }\end{array}$ \\
\hline
\end{tabular}

- Investment in capital: the investor has the possibility to invest his savings through the subscription of securities or participation in the capital of the

- Donation with counterpart: the investor requires company;

a symbolic and non-cash counterpart;

- Bond investment: the investor finances the project through the subscription to the bond issued by the project holder.

- Solidarity loan: loans are granted from one person to another without any interest.

Source: Authors.

Moreover, according to a study by Afrikstart (Note 5), the African market includes 57 platforms that raised a total of US\$32.3 million in 2015. South Africa alone had 21 platforms, followed by Nigeria with 9 and Morocco with 4 . The money raised by these platforms enabled the financing of SMEs ( $\$ 17.7$ million) and real estate projects $(\$ 13.6$ million). The balance sheet of all crowdfunding activities carried out in Africa reveals that in 2015, 32\% of the projects financed have a strong social impact, followed by entrepreneurship with $21 \%$ and then creative projects with a share of 5\%. In addition to this, the annual growth rate in 2015 is estimated at 101\% (Note 6) and the potential for financing through crowdfunding is estimated by the World Bank at nearly 2.5 billion dollars by 2025 (Note7).

As for the types of crowdfunding, we distinguish four main categories:

Simple donation (no quid pro quo): the platforms that encourage this type of crowdfunding are part of the Social and Solidarity Economy and try to propose projects whose bearers are excluded from the banking system and living in precarious situations, or projects with the objective of local development such as the construction of schools, hospitals, etc.

Donation with counterpart: this is generally associated with projects of a socio-cultural nature. In fact, the project leader receives donations in return for a non-financial reward. For example, the contributor can buy t-shirts bearing the name of a singer in advance to enable him or her to finance the recording of his or her album.

The loan: After obtaining a loan, the contributor expects repayment of the principal with or without interest. Indeed, the investors can recover their money and keep it for themselves or use it to finance another project. We specify that interest-free loans are practically intended for actors of the solidarity and social economy. It is worth mentioning solidarity loan platforms can play the role of a complement to microcredit by establishing partnerships with microcredit institutions. We cite the example of the American platform KIVA, which enables this type of crowdfunding.

In the case of the interest-bearing loan mode, the investor selects the project that suits him in terms of profitability while seeking to minimise the risk. In fact, the interest rate is set based on an interest rate that comprises a base rate plus a risk premium, the latter being defined according to the feasibility of the project and the risk of default of the counterparty. The interest rates applied are lower than the rates charged by banks.

Investment: this category of crowdfunding is based on the investment of the general public in the capital of the company. It is, in fact, an equity investment Hornuf \& Shwienbacher (2014). The contributors thus become shareholders in the company in which they have invested.

\section{The Legal Framework of Crowdfunding in Morocco}

Law ${ }^{\circ} 15-18$ defines a scheme of crowdfunding activities in Morocco and the types of financing it allows: Crowdlending, Crowdequity and Donation Crowdfunding.

\subsection{The Legal Procedures of Crowdfunding in Morocco}

Law $n^{\circ} 15-18$ aims at regulating the framework of crowdfunding in Morocco, by defining procedures concerning:

- The creation of the status of manager of collaborative funding platforms (CFP); 
- The specification of the mechanism for approving SFCs and supervising collaborative financing activities;

- The definition of procedures and terms for the creation and operation of CFPs;

- Defining the commitments and obligations of the SFC, particularly in terms of public information, publicity and reporting;

- Defining the rules that apply in terms of prior verification of projects to be financed, securing transfers and protecting contributors;

- The establishment of ceilings in terms of the amounts to be raised per project and per contributor for the different forms of financing;

- The definition of specific rules for each of the three forms of collaborative funding (Note 8).

We specify that after being adopted in the Council of Government in August 2019, and after two long years in the legislative circuit, the law 15-18 concerning Crowdfunding became official in Morocco, on March 2021.

\subsection{Actors in Crowdfunding in Morocco}

The activities of crowdfunding in Morocco are governed by law $n^{\circ} 15-18$. This law requires the intervention of the following actors:

- The project leaders;

- Collaborative financing companies (SFC);

- Collaborative financing platforms (PFCs);

- Central Bank of Morocco (BAM);

- Moroccan Capital Markets Authority (AMMC).

In fact, the main role of a CFS is to manage one or more PFCs. It can also provide advice to project leaders, advertise the various projects presented on the platforms under its control, and manage fundraising on behalf of the contributors. It should be noted that the procedures, terms and conditions for carrying out these activities are defined by regulation based on proposals, depending on the situation, from BAM or AMMC.

It should be noted that the activity of SFCs specialising in "loan category" or "donation category" crowdfunding operations is directly controlled by BAM. Whereas those whose activity falls under the "investment category" are directly controlled by AMMC. As far as the amount of financing is concerned, the law specifies that the funds raised in favour of the same project, within the framework of crowdfunding, are capped at 5,000 KDH. Thus, the contributions of a natural person, for each project, cannot exceed $250 \mathrm{KDH}$ and at the end of a calendar year, cannot exceed $500 \mathrm{KDH}$. Moreover, any crowdfunding operation in the donation category exceeding $500 \mathrm{KDH}$ must be authorised by Central Bank of Morocco.

\section{Crowdfunding and Development in Morocco}

In order to meet the challenges related to the promotion of entrepreneurship in Morocco, especially in the SSE sector, crowdfunding seems to be an effective financing tool that can complement the existing offers and sources of funding in Morocco. Due to its digital nature, crowdfunding is today a new financing tool that should involve the entire population, including the Moroccan diaspora, in the economic and social dynamics; let us specify over five million Moroccans are abroad and can also raise funds through crowdfunding platforms to finance projects with a social and economic impact. In addition, crowdfunding also has its place in various public policies and strategies that advocate for inclusive economic development. As evidenced by the publication of the law No. 15-18 of crowdfunding, in March 2021, in the official bulletin.

Regarding its relationship with the social and economic development of the country, crowdfunding will channel collective savings towards new investment opportunities and mobilize alternative sources of funding to support young project holders, very small, small, and medium enterprises in Morocco.

\section{The Impact of Crowdfunding on the Social and Solidarity Economy in Morocco: An Empirical Study}

\subsection{Methodology}

In order to respond to our research question which targets the study the impact of crowdfunding on the social and solidarity economy in Morocco, we used a methodology based on documentary research as well as a quantitative survey via a questionnaire. 


\subsection{Literature Review}

By analysing several documents related to the Crowdfunding concept, we were able to obtain relevant information which helped us to write the first part of this article and to compile a bibliography. It should be noted that the resources used are mainly books, reports and scientific articles. In addition to the documentary research, we also relied on information from the platforms that carry out the activities of the Crowdfunding.

\subsection{Quantitative Analysis}

We carried out a survey through a questionnaire which includes a series of questions asked in a structured and logical manner. The target population consists mainly of directors and managers operating in the banking and financial sector, civil servants, entrepreneurs, professors of economics and management and $\mathrm{PhD}$ students in economics and management. The objective is to collect statistical data that enable measuring the possible impact of crowdfunding on SSE in Morocco.

\section{Presentation of the Results}

We were able to collect 40 responses from a sample of 28 women and 12 men, with the following age structure: The age of 21 persons varies between 18 and 25 years old; The age of 12 persons is between 26 and 35 years old; 4 persons are between 36 and 45 years old, and; 3 persons are over 45 years old. Concerning the professional situation, our sample includes 4 entrepreneurs, 5 civil servants, 8 employees and $23 \mathrm{PhD}$ students, one of whom is a civil servant and the other two work in the banking and financial sector. It is important to note that the banking and financial sector is ranked first, as the 12 people in our sample are managers and financial directors. Next comes the Services \& Administration sector, this time with 5 people. In 3rd place is the Trading sector, which is represented by 2 people. The table below shows the sectors of activity in which each member of our sample is engaged.

Table 3. Members of our sample by sector of activity

\begin{tabular}{lll}
\hline Sectors of activity & Number of employees & Percentage \\
\hline PhD Student- Researchers* & 15 & 37.5 \\
\hline Finance - Banking - Insurance & 12 & 30.0 \\
\hline Services - Administration & 5 & 12.5 \\
\hline Import - Export - Trade Intermediary & 2 & 5.0 \\
\hline Agrifood, Horticulture, Livestock & 1 & 2.5 \\
\hline Food and beverages & 1 & 2.5 \\
\hline Building and Public Works & 1 & 2.5 \\
\hline IT - Telecommunication & 1 & 2.5 \\
\hline Paper - Cardboard - Printing & 1 & 2.5 \\
\hline Coatings- Painting - Surface treatment & 1 & 2.5 \\
\hline Total & 40 & 100 \\
\hline
\end{tabular}

Source: survey conducted by authors.

(*) Not concerned by the classification by sector of activity.

The findings from the survey show that $77.5 \%$ of our sample, i.e. 31 respondents knows the concept of the solidarity and social economy. For this purpose, we mention that SSE includes two terms "social economy" and "solidarity economy". The first term refers to associations, cooperatives, mutual societies and foundations. The second term refers to organisations that aim to be of high social utility, for example those that give priority to hiring people in difficulty or helping them to create an activity with a social impact, or by practising forms of exchange that impact high social and environmental.

Furthermore, after analysing the results of our survey, it turned out that 18 people in the sample had already heard of Crowdfunding. This is indeed:

- $8 \mathrm{PhD}$ students, 7 of whom are women; 
- One woman working in the food and beverages sector;

- One man working in the building and public works sector;

- 2 men and 3 women working in the banking sector;

- An entrepreneur working in the painting sector, and;

- 2 professors of economics and management.

Table 4. Knowledge of crowdfunding, its forms and its legal law in Morocco

\begin{tabular}{|c|c|c|c|}
\hline & \multicolumn{3}{|c|}{ Knowledge of "Crowdfunding" } \\
\hline & & No & Yes \\
\hline \multirow{2}{*}{$\begin{array}{l}\text { Knowledge of the legal framework of } \\
\text { crowdfunding and its main forms }\end{array}$} & No & 22 & 7 \\
\hline & Yes & 0 & 11 \\
\hline
\end{tabular}

Source: survey conducted by authors.

Table 4 shows that only 11 of these people are aware of the legal framework of crowdfunding in Morocco and its different forms.

With regard to the participants' perception of the impact of crowdfunding on the development of the solidarity and social economy in Morocco is concerned, the results of our survey are optimistic.

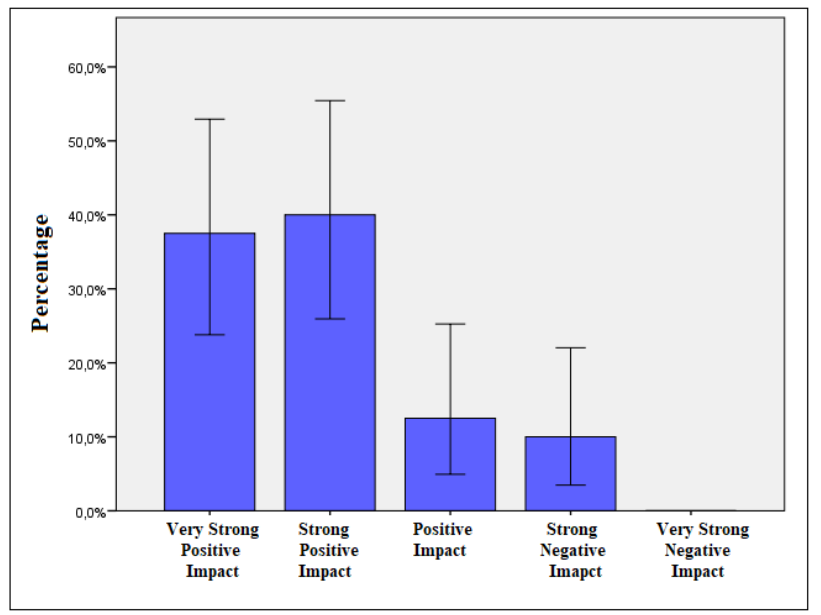

Figure 1. Impact of crowdfunding on SSE in Morocco

Source: survey conducted by authors.

As illustrated in the graph above, $37.5 \%$ of our sample believes that Crowdfunding would have a very positive impact on the development of the activities of the solidarity and social economy in Morocco. $40 \%$ of them foresee a positive impact and only $10 \%$ believe that this new funding alternative would have a negative impact on SSE in Morocco.

In fact, by type of products, the same survey shows that "Crowdequity" would have more impact, followed by "Donation crowdfunding" and then "Crowdlending". 
Table 5. Relative impact of crowdfunding products on SSE in Morocco

\begin{tabular}{ll}
\hline Forms of Crowdfunding in Morocco & $\begin{array}{l}\text { Number of people believing that this product has } \\
\text { more impact on SSE in Morocco }\end{array}$ \\
\hline Crowdequity & 14 \\
\hline Donation Crowdfunding & 9 \\
\hline Crowdlending & 7 \\
\hline \multicolumn{1}{c}{ Total * } & 30
\end{tabular}

(*) The other 10 persons are indifferent between the 3 forms and believe that they would have the same impact on the development of SSE.

As mentioned in the first part of this article, the Moroccan law on crowdfunding requires that the envelope allocated to each project within the framework of collaborative financing must not exceed 5 million dirhams. Accordingly, the present study results from the survey show that only $30 \%$ consider that the funds raised will be sufficient to start and develop a project in the framework of the social and solidarity economy.

Table 6. Analysis of the impact of crowdfunding on SSE according to the envelope allocated to the projects and the level of knowledge of crowdfunding and SEE by the sample

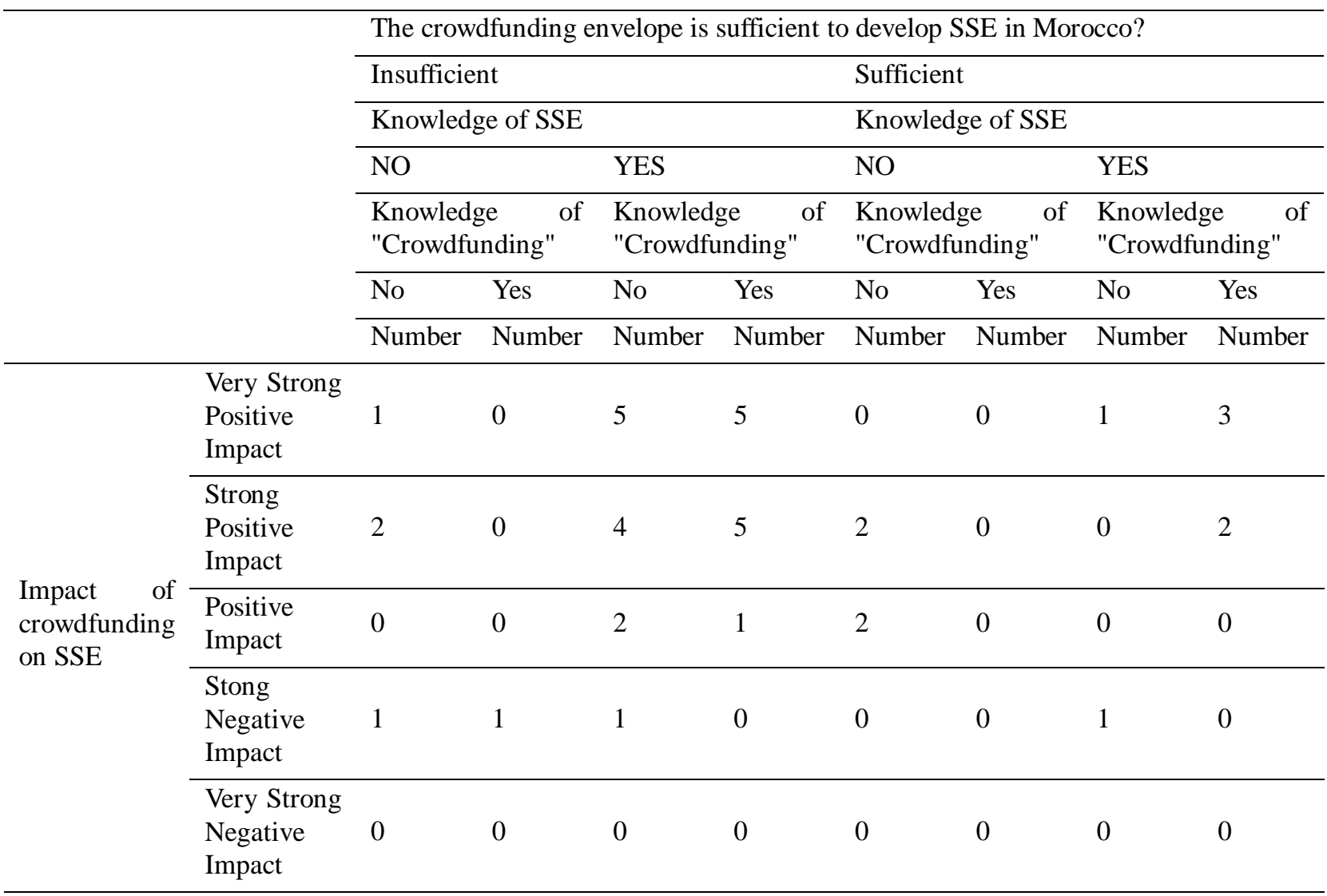

Source: survey conducted by authors.

The analysis of the results shows that $12.5 \%$ of the sample believes that crowdfunding would have a positive impact on SSE. This first category knows about SSE, Crowdfunding and for it the $5 \mathrm{MDH}$ are sufficient to set up a project. According to the same survey, $27.5 \%$ of the sample believes that crowdfunding would have a positive impact on SSE. This second category is familiar with the SSE sector, Crowdfunding, but considers that the 5 MDH are not enough to start a project. 


\section{Discussion}

Based on the results obtained from the survey responses crowdfunding would have a positive impact on the development and growth of the social and solidarity economy in Morocco because of its capacity to replace traditional finance in terms of financing. In addition, we concluded that crowdfunding could be an alternative financing option for SSE actors or any other economic agent that encounters difficulties in financing activities with an economic and social impact. In this respect, let us recall that crowdfunding in Morocco offers 3 types of products:

- Donations (with and without counterpart);

- Loans (practically with an interest rate lower than that offered by the banks);

- Crowdequity (the raising of funds through investment in the company's capital).

We specify that, the average impact of crowdfunding on SSE in Morocco is estimated at 1.95 on a scale ranging from 0 to 5 , with a standard deviation equal to 0.95 . This result is considered satisfactory.

\section{Conclusion}

Nowadays, crowdfunding presents itself as a real alternative of financing which could contribute to the development of the structures of the social and solidarity economy in Morocco. It is essentially intended for Start-ups', Very Small Companies, Cooperatives, Associations and any other economic agent having difficulties in raising funds in the early stages of a project that is too risky and complex in the eyes of the banks.

In fact, the different products of the Crowdfunding will present an innovative and more relevant response to the multiple economic, social and environmental challenges in order to succeed in Morocco's societal project which aims at catching up with sustainable development.

The three forms of Crowdfunding (crowdlending, Crowdequity and donation crowdfunding) will strengthen the financial inclusion of SSE actors, support social and economic development in Morocco and lead collective savings towards new opportunities. However, the success of this new financing method is conditioned by the existence of certain elements, notably the implementation of a framework law for Crowdfunding.

In view of the above and based on the results obtained from our survey, we confirm the first starting hypothesis that crowdfunding products will present an effective solution for the development of SSE in Morocco.

\section{References}

Bouhmouch, M., \& Markria, D. (2016). Etude de faisabilité sur le Crowdfunding au Maroc en vue de l'implication de la Diaspora dans le développement du Maroc (p. 114). Organisation Internationale Pour les Migrations.

Cécile, P. (2018). Le crowdfunding (p. 128). France: Presses Universitaires de France.

Gilles, L., \& Patrick, H. (2014). Le grand livre de l'économie PME 2015 (p. 1024). France: Gualino.

Kouame, K. (2018). Facteurs explicatifs du succès ou d'échec des opérations de crowdfunding pour des projets d'entrepreneuriat: Essai de construction d'un modèle conceptuel explicatif (p. 380). Université Alassane Ouattara, République de Côte d'Ivoire.

Patrick, N. (2018). Le développement du Crowdfunding dans la CEMAC: Opportunités, freins et rôle de la Banque Centrale. Bank of Central Africain States, (2), 18.

Sophie, R. (2014). Citizen-sourcing: definition and stakes for cities. Politiques \& Management Public, 2(32), 215-237.

Tadjousti, H., \& Zahi, J. (2018). Financing of innovation in Morocco: What future for the crowdfunding. International Journal of Innovation and Applied Studies, 23(4), 676-683.

Trabelsi, D., \& Olivier, J. (2018). Le Crowdfunding: Concepts, réalités et perspectives. Revue Française de Gestion, (273), 70-81.

\section{Notes}

Note 1. Kiva is an international nonprofit, founded in 2005, in San Francisco, with a mission to expand financial access to help underserved communities thrive. www.kiva.org

Note 2. Indiegogo is a crowdfunding website founded by Danae Ringelmann, Slava Rubin, and Eric Schell in 2008. It is based in San Francisco, California. www.indiegogo.com

Note 3. Kickstarter is an Americain Company specialized in crowdfunding, founded in 2009. www.kickstarter.com 
Note 4. KissKissBankBank is a French Company specialized in crowdfunding, Founded in 2010 by Ombline Le Lasseur, Vincent Ricordeau and Adrien Aumont. www.kisskissbankbank.com

Note 5. Afrikstart is an African Crowdfunding Platform set to provide Funding, training and mentoring to entrepreneurs in Africa. www.afrikstart.com

Note 6. We have collected these statitics from the Massolution Crowdfunding Industry 2015 Report. www.smv.gob.pe/Biblioteca/temp/catalogacion/C8789.pdf

Note 7. We have collected these statitics from the Report "Crowdfunding's Potential for Developing World, Report" by World Bank published in 2013. www.infodev.org/infodev-files/wb_crowdfundingreport-v12.pdf

Note 8 . Law ${ }^{\circ} 15-18$ concerning crowdfunding in Morocco.

Note 9. https://www.capital.fr/economie-politique/crowdfunding-1316742

Note 10. https://www.kiva.org/about

Note 11. https://www.kickstarter.com

Note 12. https://www.indiegogo.com

Note 13. https://www.kisskissbankbank.com

Note 14. https://www.afrikstart.com

\section{Copyrights}

Copyright for this article is retained by the author(s), with first publication rights granted to the journal.

This is an open-access article distributed under the terms and conditions of the Creative Commons Attribution license (http://creativecommons.org/licenses/by/4.0/). 